\title{
ECOLOGICAL AND TECHNOLOGICAL ASPECTS OF THE CULTIVATION OF COMMERCIAL YOUNG BLUE FOX (VULPES LAGOPUS) WITH DIFFERENT METHODS OF WATERING
}

\author{
T. V. SHEVCHUK, Doctor of Agricultural Sciences, Associate Professor, Depart- \\ ment of Animal Breeding and Water Bioresources \\ Vinnitsa National Agrarian University \\ M. G. POVOZNIKOV, Doctor of Agricultural Sciences, Professor \\ National University of Life and Environmental Sciences of Ukraine \\ E-mail:Tatjana.Melnikova@ukr.net,povoznikov@i.ua
}

\begin{abstract}
Water quality is one of the main conditions for the normal functioning of living beings. The use of alcohol plays an important role in the commercial cultivation of farm animals. The production of clean livestock products directly depends on the sanitation and hygiene of its technological units. Therefore, the study of ecological and technological aspects of drinking farm animals is relevant and carries elements of scientific novelty. The purpose of our research was to study the ecological and technological aspects of the production of furs of fox (Vulpes lagopus) with the introduction of mechanized watering. It was found that after 2-12 hours after the manual distribution of water in open feedings, the $\mathrm{pH}$ of the water is significantly reduced, turbidity rises, and there is a specific odor and color. When mechanized watering of fox from an individual drinker, water indicators remain with normal limits. Experimentally proved that the method of watering does not affect on the animals' weight and growth. However, there is an improvement in the quality of fox skins (Vulpes lagopus) in the experimental group. In the experimental group there was a decrease in defects of flax, better color and skin style. Thus, in animals of the experimental group, when evaluating the skin, a larger proportion of the products of the first color group was set to $2 \%$, the first group of defects - by $4 \%$, the first - by $3 \%$. Therefore, the skins of the second group were valued higher than the control of $48 \mathrm{UAH}$. Capital investment in the introduction of mechanized drinking animals pays off in one year, therefore, to improve the quality of fur, increase profitability and production of environmentally friendly products, it is advisable to transfer kennels to automated watering.
\end{abstract}

Keywords: water quality, livestock breeding, blue fox, retention, watering.

\section{Introduction.}

The modern technology of livestock production involves the use of not only a closed cycle of production, but also full mechanization and automation of production processes. For the implementation of the achievements of sci- 
entific and technological progress in production, maximum possible manifestation of the genetic potential of animals and the receipt of high-quality and environmentally friendly products can be achieved.

Farming is one of the youngest livestock industries, which is constantly being improved and modernized. Today, predatory animals are selected for tolerance to humans, and therefore easily adapt to the work of equipment, machines and mechanisms that facilitate work. Therefore, the mechanization of production processes in animal husbandry is relevant. In the progressive and large breeding farms of the world (the Netherlands, Norway, Finland, Denmark, USA, Poland), most of the processes of forage preparation, transportation, primary processing of fur are automated or mechanized. In individual farms, mechanized water supply to the shaft and even cages of animals is set up. This kind of watering allows you to keep the quality of drinking water at the standard level, economically, at the request of animals, to waste water, if necessary, to dispense therapeutic or biologically active drugs [4, 20].

In Ukraine, most farms use manual watering methods - cheap and simple, but not without disadvantages: labor-intensive, non-hygienic and long-term. Therefore, large domestic animal farms should switch to mechanized. However, some technological issues and technical solutions to this method of drinking fur-bearing animals are not yet fully explored. Therefore, the purpose of our work was to investigate the productivity of commercial young blue fox (Vulpes lagopus) in different ways of drinking, to assess the economic feasibility of introducing a mechanized method and to develop proposals for production. The use of water for drinking different farm animals is determined by the genetic, individual, technological features of their content [3].

The level of drinking water consumption can fluctuate for individual species from several grams to tens of liters. For centuries-old history of domestication and cultivation of farm animals, appropriate rules and sanitary rules have been developed that determine the quality of water, its quantity for water supply and service, systems, methods of watering. The norms of water consumption are also clearly regulated by different kinds of fur animals: for commercial young mink, ferrets, frescoes per day it is necessary up to 3 liters of water (taking into account the costs of production of feed mixes, washing of equipment, cleaning of industrial premises), foxes and foxes - 6-7 liters, muskrat and rabbit - up to 31 , nutria - up to 0,51 . These norms do not include water consumption for household needs (shower, wash basin, car wash disinfection, manure cleaning, heating and food processing) [1].

Important in maintaining a satisfactory state of health and in obtaining genetically determined productivity of animals is the regime of drinking animals. Therefore, in science, requirements have been developed regarding the multiplicity of water consumption by individual species and genus-age groups of farm animals. In animal husbandry, several systems and methods of watering farm animals are used. In this case, automation and mechanization of processes are widely used. In particular, water supply mechanization includes raising, feeding and distributing water. The water supply system includes a water source, water intake structure, a pumping station, a treatment plant, a water tower, an external and internal 
plumbing, water intake devices and devices for feeding farm animals [25].

As a rule, animals are fed with automatic drinking, bucket, trough and directly from the source. It is better to use car washes. In state sanitary norms and rules it is stated that only those with a sanitary protection zone consisting of 3 belts: strict regime, belt limits and belt of observations are allowed to use water sources. The first belt covers the territory in which there is a water source, water intake plumbing, objects of treatment and storage of water. It is prohibited to reside and temporarily find persons who do not work at water supply facilities.

In animal husbandry mode should be as much as possible to resemble the natural conditions of the existence of fur animals. Small animals: ferrets, mink, sable are inhaled from automatic drinkers voluntarily. Large animals: foxes, foxes, raccoon dogs - every day (in the absence of auto-typing). Pregnant and lactating females should be swallowed. This can be done by introducing mechanized watering, or 2-3-times water distribution [4].

In the winter, fur animals that are kept in open constructions can be given snow and ice. The latter is rich in minerals, so it better quenches thirst [8]. Daily requirement of fur animals in water consists of expenses for drinking, preparation of feed, washing equipment and utensils, cleaning of premises. Important in the hygiene of fur animals is the temperature control of water, because hyperthermia threatens not only the formation of furs, but also the life of animals. Yes, M.P. Vysokos and others [25] singing. Recommends for farms located in the steppe and forest-steppe zones in the heat $\left(28-30^{\circ} \mathrm{C}\right)$ to carefully observe the state of animals, and from 14.00 , the beasts of the western line of cages should be fed to drinking cool wa- ter 2 times more often, compared with the eastern line of cells in buildings.

Under conditions of the south can be arranged drinking-pools. Such a system of uninterrupted water supplies reduces the incidence of fur animals and mortality rates, increases the weight of animals and the size of the skins by $30 \%$ [18]. For cell breeding of fur animals, different methods of drinking are used: non-mechanized - the distribution of water is carried out manually to the combined, semi-mechanized - from the portable flexible hose to the drinker's individual and group or automated. The latter method involves the use of automatic drinkers to which water is supplied through the water supply system $[25,12]$. During a semi-automatic feeding method, a flexible hose up to $50 \mathrm{~m}$ (half the length of the shell) is put on the edge of the water supply riser, and the worker, passing along the cells, fills the drink with water.

In the organization of automated watering use individual drinkers of different designs. For example, a nipple drinker consists of a brass or plastic body with a thread and head with a valve. An antifoam is screwed into a polyethylene tube (diameter $20-25 \mathrm{~mm}$ ), which runs along the outside of the shell, the head of the drill with the rod through the mesh of the cell is inside the cell. The beast presses the nose to the stem, removes the rubber valve, and the water pours out a weak tufts. It is important to have a constant pressure in the split tubes. This is achieved by means of a reducer with a pressure reducing filter, or raised to a certain height of the tank.

A variety of nipple auto-saw is a cup for a lever valve auto-feeder, which has a bowl and valve of different design. Water in the bowl comes when pressed on the lever. For example, AУ3-80 automatic 
drinker of the design of ОПКБ НИИПЗК consists of a bowl with a capacity of $80 \mathrm{ml}$ with a horn in the cage through the mesh line. The valve body with a swing valve is converted to the connection through the opening of the bowl [7].

For reliable sealing the valve is provided with a rubber washer of the sealant and fixed with a plastic spring. The beverage is pressed to the grid and fixed obliquely or horizontally with a spring fastening. Water is supplied by a hose with a diameter of $10 \mathrm{~mm}$. When driving a beast, it consume water from the horn, touches the valve rod, rejects it, and water enters the bowl. The design and arrangement of the valve device provides the washing of the feed that has fallen into the bowl, the water jet when the valve is opened VNTPAPK-05.07 [15].

Float automatic drinker PP-1 and lever-float drinkers are considered convenient in operation, they work well both on hard water and on water with mechanical impurities. On block cages for young fur-bearing animals, one such car was installed on two adjacent cells. The levers of the float of the car washes can be installed on two adjacent cells of the main herd of the mink. Lack of drinking is the need for their periodic (once a week) cleaning and washing, for which in the booth PP-1 has to shoot a stub.

When streaming water in the center of the cell at a height of $20 \mathrm{~cm}$ from the floor are inserted two-row drinkers (aluminum or plastic) attach them with wire. Above the drinkers, with the help of wire plugs, fasten a polyethylene pipe, in which from below (opposite to the middle of each drinker) make holes. Through these openings in the drinking water comes the water. As the pressure in the pipe as the distance from the riser of the main water supply decreases, the aper- tures on the first feeders do less than the last ones. Such a drinking system works reliably, but inevitably the transfusion of water through the edges of the drink.

The indicated methods of watering are not without disadvantages. Thus, the first one is characterized by high costs of manual labor, water contact with air, inventory and food, the need for daily renewal of a fresh portion of water. In the case of automated drainage of fur animals, these shortcomings are eliminated, however, there is a need to maintain water temperature in the supply system in the winter months of the year, and capital expenditures for fur production are increasing. In addition, for the training of young fur animals for automatic drinkers, a long period of time is required during which a large drop of unadapted individuals may occur. Some scholars point out that the question of which type of automatic drinking is better to use for each type of fur-bearing animal is still not investigated [25].

As a result of the literary search for the chosen theme, it has been established that scientific publications have a lot of information about the organization, technical solutions and technological features of drinking farm animals, including fur animals. When cultivated, the latter use different methods of drinking: non-mechanized, semi-mechanized and mechanized. Each way has its advantages and disadvantages, which are more or less studied. However, in the scientific literature, there is a certain lack of information on the productive effect of various methods of drinking fur animals, on their impact on the quality of furs, animal health, etc. Therefore, our further research will be: studying the quality of water in different ways of feeding the predatory fur animals of the cell breeding (blue fox); comparison of 
water indicators for different methods of drinking with the norm; studying the dynamics of growth and development of commercial young during the period of growing and forming furs; establishment of peculiarities of keeping animals of animals using different methods of drinking; the study of the productive features of commercial blueberries of young blueberries for non-mechanized and mechanized watering; Proving the economic feasibility of introducing mechanized watering for the cultivation of fur animals.

\section{Materials and methods.}

The purpose of the thesis was to study the productivity of commercial young blue fox (Vulpes lagopus) for sighting methods of drinking. The object of research in our work were different ways of drinking fur-bearing animals, and the subject - the productive features of commercial young blue fox for different ways of drinking it.

The experimental part of the thesis was conducted in a private enterprise located in the village of Slobidka Rakhivetska, Duneyevka district, Khmelnytsky region. In the farmstead, three types of fur animals are grown: foxes, foxes and rabbits. The dominant species of feral animals grown on the farm are foxes. Today, $90 \%$ of all foxes belong to the silver-black colored type, $8 \%$ - red and firefly and $2 \%$ - White Caucasian and Bastardo. The animal economy operates on the principle of a closed loop. Scientific and economic experiment was carried out by the method of group-periods [14]. Control group was a commodity young fox blue, which was formed on the principle of analogues $(n=60)$. Animals of 1.5 months old were weaned from their mothers and placed two in mesh cells. The spraying was carried out with combined jets. Distribution of water was carried out manually daily. Volumes of expenditure for 1 head of commercial young blue fox (Vulpes lagopus) drinking water were regulated by the current norms [6].

The experimental group of commercial young foxes $(n=60)$ was placed in a shed with a mechanized water supply system consisting of a system of filters, a meter, a pump, a dispenser, a pressure regulator, water connections and nipple auto-squirrels, brought to each net for walking for young animals. Water samples for physic-chemical parameters in the control group were taken: during delivery, per hour and 12 hours after delivery. In the experimental group, samples were taken from 2 points - water and car washes $(n=3)$ [27].

Animal water consumption is recorded monthly. Investigation of physic-chemical indicators of water was carried out in accordance with the State Sanitary norms and regulations of DSanPiN 2.2.4-171-10 [26]. The scheme of the experiment is presented in Table 1.

Beasts of the control and experimental groups were kept under the same conditions (shelters on 60 grid wings), feeding - disposable damp mixes according to the feeding standards of Bala and others [4]. The diet consisted of meat and bone meal of chicken, blood of boiled chicken, chopped chicken legs and chicken heads, sunflower meal, steamed corn dander, vitamin and mineral supplement $[9,10]$.

The following research methods were used in the work: statistical, physic-chemical, technological, economic analysis. The growth rates of experimental animals were determined by monthly increase (10 heads from each 


\section{Scheme of experiment}

\begin{tabular}{|l|c|c|c|}
\hline \multirow{2}{*}{ Group } & \multirow{2}{*}{$\mathrm{n}$} & \multicolumn{2}{|c|}{ Features of the experiment by periods: } \\
\cline { 3 - 4 } 1 - control & 60 & $\begin{array}{c}\text { Method of drinking: unmanaged, } \\
\text { from drinkers the combined cup } \\
\text { type }\end{array}$ & $\begin{array}{c}\text { Method of drinking: unmanaged, } \\
\text { from drinkers the combined cup } \\
\text { type }\end{array}$ \\
\hline 2-experimental & 60 & $\begin{array}{c}\text { Transfer and training for } \\
\text { automatic drinkers }\end{array}$ & $\begin{array}{c}\text { Method of drinking: mechanized } \\
\text { from individual automatic } \\
\text { drinkers }\end{array}$ \\
\hline
\end{tabular}

group). The absolute and average daily increments were determined. In addition, they monitored preservation, determined the percentage of withdrawal and the causes of death $[5,25]$. After reviewing and establishing the fact of maturation of furs of commodity young blue fox, they slaughtered. The skins were filmed with a "stocking", they were masked on a "spit" manually and dried on the rules of the standard sample [2]. The dried skins were processed in a drum with the addition of sawdust, and then turned the fur out, scissors and evaluated the quality of the skins according to the standard [21]. The complex of linear and qualitative parameters determined the sale price taking into account market prices of the current year. The first group of productive features includes: length, width, area of skins and dimensional category, and to others the group of color, defects and genus. The evaluation of fresh-dry skins was carried out according to the standard scale, where the market price of the current year of the skins of the 3 dimensions category, and the group of color, grade and groups of defects was adopted for $100 \%$ of the cost.

The digital material was processed statistically for N. A. Plohinsky [13]. The resulting digital data was processed using the MS EXEL 98 and Windows program, statistically processed by Student. The results were considered statis- tically significant at $p<0.05, p<0.01$, $p<0.001$. In the table material of the work the following symbols are taken: $* p<0.05, * * p<0.01, * * * p<0.001$.

\section{Results.}

According to organoleptic parameters, water from the water supply system, which is fed to the farmstead and handed over to drinking water, and also supplied to the carcasses of foxes (Vulpes lagopus), meets the current sanitary standards DSanPiN 2.2.4-171-10 [26]. Already after 12 hours of stay in a combined feed for young animals, water samples were significantly lower than the control smell (by $56.4 \%$ ) and turbidity (by $1.12 \mathrm{mg} /$ $\operatorname{dm} 3)(p<0.01)$ (Fig. 1) .

It is clear from the diagram that after the handing out of water, manually varying physical and chemical parameters. Thus, there was a significant $(p<$ 0.001 ) decrease in acidity from 6.55 to 5.49. Studying samples of water from car washes at mechanized watering of fossils did not reveal any significant differences. Organoleptic and physic-chemical parameters were at the level of control and conformed to the norms.

Studying separate indicators of ecological safety of drinking water in different ways of drinking fur-bearing animals found that the water samples of the 2-experimental group did not differ from the 

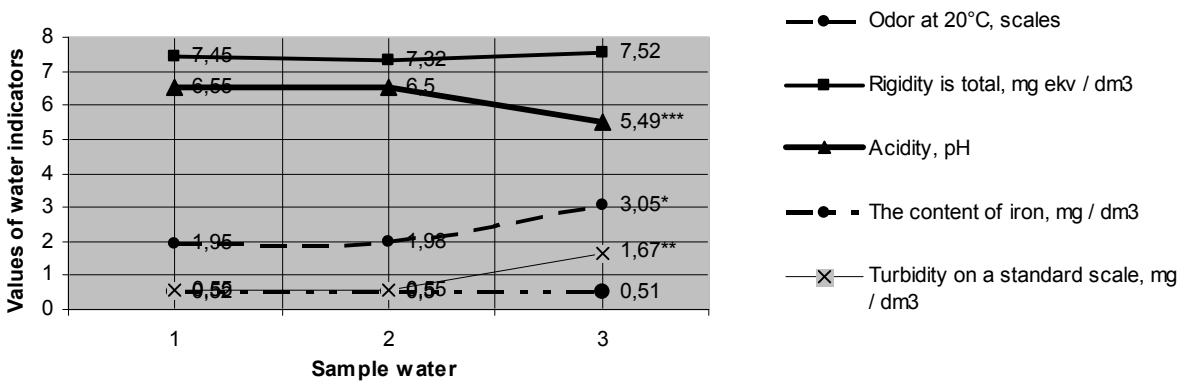

Fig. 1. Dynamics of water quality indices during non-mechanized milking of blue fox (Vulpes logopus) during technological periods, $M \pm m(n=3)$ :

1 - from the water supply, 2 - from the drinking water after 1 hour after handing out, 3 - after drinking in 12 hours after handing out

parameters of control and norm. At hand distribution of water, after 1 hour after distribution, there was a slight increase in the content of dry residue, chlorides and increase in color indices (Fig. 2).

The study of the dynamics of live weight showed that the animals of the experimental group, which were injected mechanized with the automated supply of water, did not yield to weight control and increments. The study of the safety of young animals during the growing season showed that, before the animals were transferred to different methods of drinking, the percentage of livestock withdrawal was equal in the control and experimental groups. During the scientific and economic experiment it was revealed that the commodity youngsters in the 2nd group were characterized by less leave because of the causes of illnesses and injuries and exceeded the analogues for monitoring the level of preservation by $3,3 \%$ (Table 2 ).

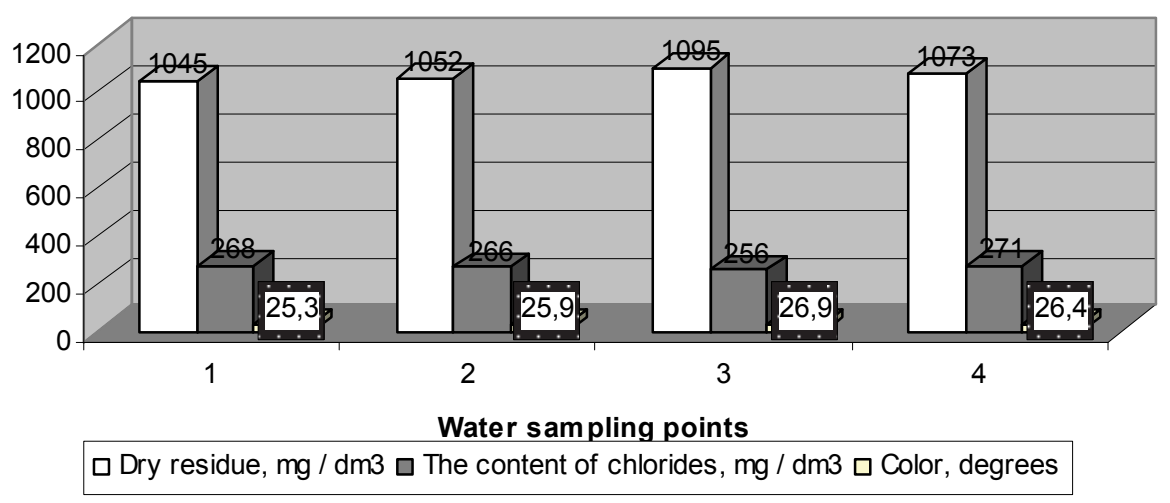

Fig. 2. Separate indicators of the quality of water samples for different methods of drinking commercial young fox (Vulpes lagopus):

1 - from the water supply, 2 - from the drinking water after 1 hour after distribution (control group), 3 - after drinking in 12 hours after handing out (control group), 4 - with an automatic drinker (experimental group) 


\section{Dynamics of live weight and consistence of stock of young blue fox (Vulpes lagopus)}

\begin{tabular}{|l|c|c|}
\hline \multirow{2}{*}{ Index } & \multicolumn{2}{|c|}{ Grop } \\
\cline { 2 - 3 } & 1-control & 2- experimental \\
\hline Live weight at the beginning of the main period, $\mathrm{kg}$ & $3,26 \pm 0,31$ & $3,31 \pm 0,33$ \\
\hline Live weight at the end of the experiment, $\mathrm{kg}$ & $6,85 \pm 0,25$ & $6,89 \pm 0,36$ \\
\hline Absolute increment, kg & $3,59 \pm 0,28$ & $3,58 \pm 0,28$ \\
\hline Average daily gain, g & $32,64 \pm 0,86$ & $32,55 \pm 1,23$ \\
\hline Number of animals when staged on the test & 60 & 60 \\
\hline Number of animal at the end of the experiment & 55 & 57 \\
\hline Animals died, total: & 5 & 3 \\
\hline including those killed through: illnesses & 2 & 1 \\
\hline - injuries & 2 & - \\
\hline - other reasons & 1 & 2 \\
\hline Conservation of young animals, $\%$ & 91,7 & 95,0 \\
\hline
\end{tabular}

In our opinion, the use of mechanized watering animals does not compete for water, less conflicts and injuries, and for isolation and water supply, bacterial contamination and less pathogenic microorganisms develop.

Productive signs of blue fox were estimated on the basis of linear and qualitative indicators of fresh-dry skins. Table 3 shows the results of studying the width, length and area of skins of experimental animals. As for the introduction of a new watering method, as can be seen from the table data, no significant changes in the linear measurements of animal skins were detected.
During the study of qualitative indicators of furs of commercial young blue fox (Vulpes lagopus) it was found that the animals of the 2-experimental group were dominated by analogs for controlling the number of skins and color groups by $2 \%$, the first group of defects - by $4 \%$, grade I - by $3 \%$ (Table 4 ).

The material presented suggests that the skins of commercially-grown young animals were evaluated above $3.9 \%$ control. The best qualitative indicators of skins, in my opinion, in animals of the 2 group were revealed because they found fewer flaws in them: scratching, rubbing furs, holes that were found in animals in

\section{Linear measurements of fresh-dry skins of commercial young fox (Vulpes lagopus), $M \pm m$}

\begin{tabular}{|l|c|c|}
\hline \multirow{2}{*}{ Index } & \multicolumn{2}{|c|}{ Group } \\
\cline { 2 - 3 } & 1-control $(\mathrm{n}=55)$ & 2-experimental $(\mathrm{n}=57)$ \\
\hline Skin length, sm & $75,67 \pm 3,35$ & $77,05 \pm 4,59$ \\
\hline Skin width, sm & $13,0 \pm 0,31$ & $13,0 \pm 0,62$ \\
\hline Skin area, dm2 & 19,67 & 20,03 \\
\hline
\end{tabular}




\section{Qualitative indicators of the skins of commercial young blue fox (Vulpes lagopus), $\%$ of the livestock in the group}

\begin{tabular}{|l|c|c|}
\hline \multirow{2}{*}{ Index } & \multicolumn{2}{|c|}{ Group } \\
\cline { 2 - 3 } & 1- control $(\mathrm{n}=55)$ & 2- experimental $(\mathrm{n}=57)$ \\
\hline Category size: 1 & 75 & 78 \\
\hline 2 & 15 & 15 \\
\hline 3 & 10 & 7 \\
\hline Color group: I & 77 & 18 \\
\hline II & 13 & 2 \\
\hline III & 10 & 89 \\
\hline Group of bugs: 1 & 85 & 10 \\
\hline 2 & 12 & 0 \\
\hline 3 & 3 & 92 \\
\hline 4 & 0 & 8 \\
\hline Class: I & 89 & $103,7 \pm 6,33$ \\
\hline II & 11 & $1545,00 \pm 23,05$ \\
\hline Skin evaluation, $\%$ & $99,8 \pm 9,62$ & \\
\hline The price of sales of skins, UAH & $1497,00 \pm 65,84$ & \\
\hline
\end{tabular}

the control group. It can be assumed that the use of individual drinking nipple beverages does not interfere with the fur of animals with so much water, and therefore does not soak and do not spoil. Therefore, the skins of experimental animals were estimated at $48.00 \mathrm{UAH} / \mathrm{pc}$. more expensive than in the control group.

The calculation of economic indicators has shown that the use of a mech-

\section{The economic efficiency of growing the commercial young blue fox (Vulpes lagopus) in different ways of drinking}

\begin{tabular}{|l|c|c|c|}
\hline \multirow{2}{*}{ Index } & \multicolumn{2}{|c|}{ Group } & \multirow{2}{*}{ Divergence } \\
\cline { 2 - 4 } & 1-control & $\begin{array}{c}\text { 2-experi- } \\
\text { mental }\end{array}$ & \\
\hline Number of animals in the group & 60 & 60 & - \\
\hline Conservation of livestock, $\%$ & 91,7 & 95,0 & 3,3 \\
\hline Total production costs for growing season, UAH & 62880,00 & 66026,88 & $+3146,88$ \\
\hline Incl. the introduction of a new method of drinking & - & 3146,88 & $+3146,88$ \\
\hline Cost per unit of production, UAH & 1048,00 & 1158,37 & $+110,37$ \\
\hline Revenues from sales, UAH & 82335,00 & 88065,00 & $+5730,00$ \\
\hline Sales unit price, UAH & 1497,00 & 1545,00 & $+48,00$ \\
\hline Net profit, UAH & 19455,00 & 22038,12 & $+2583,12$ \\
\hline Profitability level,\% & 30,94 & 33,38 & $+2,44$ \\
\hline
\end{tabular}


anized method for the feeding of young wildlife of blue fox (Vulpes lagopus), even for the increase of total production costs for the implementation of the project, causes an increase in the selling price of skins by UAH 48.00 , and thus contributes to an increase in total income per group on 2583,12 UAH and the level of profitability by $2,44 \%$ (Table 5 ).

From the table data it is clear that for the arrangement of a mechanized method of drinking commercial young blue fox (Vulpes lagopus) in one typical shed for 60 goals it is necessary to spend up to $3147,88 \mathrm{UAH}$. The recoupment of the introduction of the mechanized method of drinking young blue fox (Vulpes lagopus) is 1.21 years.

Consequently, in the course of scientific and economic experiment, we have proved not only economic expediency, but also a productive effect of the transfer of animal husbandry, and, in fact, the cultivation of blue fox (Vulpes lagopus), on an automated way of drinking.

\section{Discussion.}

Water, as the source and environment of the existence of living on Earth, is of the utmost importance. It participates in metabolism, is a good solvent, causes osmotic pressure of cell membranes. Therefore, the consumption of water by a living organism is an exclusive need for it. Note also that in nature the water cycle is continuously carried out. However, there are regions where there is a shortage of water, especially drinking water. The level of water supply for farm animals depends on their productivity directly [19]. The levels of water consumption by animals are definitely scientific. In the world, different animals have wide ranges of water intake. Separate animals, such as wild animals, prairie, savannah, can be waterless for a long time. For example, a fish Protopterus can be half a year without water for a period of drought and lose up to half the weight of the body. Animals of such regions have cycle of ontogenesis: from drought to flood. On the contrary, Arctic animals can use ice and snow to meet water needs. These animals include arctic owls, geese, foxes, bears and deer. By taming and domestication of some animals, a person tries to reproduce natural living conditions during captivity and cultivation in captivity. Therefore, for a long time, scientists from all over the world were engaged in studying the issues of drinking animals of different species.

Great experience has been gained and new technological solutions have been obtained for providing water to farm animals. Currently, there are three main methods of feeding farm animals: manual (non-mechanized), semi-automatic and automated [7, 17]. As scientists point out, during manual feeding of farm animals, the costs of manual labor increase, watering of the water is caused by pathogenic bacteria. Therefore, this type of watering is considered extensive, although it is the simplest and cheapest. In small commodity farms it is used throughout the world. The most promising today is a mechanized way of drinking. In livestock it is implemented by complex mechanization and automation. At the same time, from the point of catch the water enters through the water supply system and the system of cleaning and disinfection in the car washes. Advantages of its method is that farm animals individually consume water as needed, at any moment of time (without limitation), the hygienic characteristics of water are preserved. This way contributes to the economical use of water, provides clear 
control of costs, is able to drink with water therapeutic or prophylactic drugs to certain technological groups of animals. Among the disadvantages of the mechanized method of drinking can be noted large material costs of installation and operation, the difficulty of studying animals in autopilots. This is confirmed by our research. It is necessary to use up to $4000 \mathrm{UAH}$ for the maintenance of mechanized water for one shade to keep 60 foxes (Vulpes lagopus), and the payback period is 1.21 years.

As know, the quality of drinking water affects the health of farm animals. When water quality deteriorates, the animals reduce their consumption [24]. In this case there is dehydration, blood congestion, thrombosis, anoxaemia. In the future, animals refuse to eat, immunity decreases, bacteria or viruses become intoxicated. Due to the negative effect of the species of poor quality, the animal may perish. This is confirmed by our research. The polar fox (Vulpes lagopus) of the control group, which were kept under unmanned water, had a 4.3 $\%$ lower stocking density. In this group there was an increase in mortality due to trauma and disease [22].

By studying the productivity of fox (Vulpes lagopus) for different methods of weeding, we found that the animals in the experimental group observed an improvement in the quality of furs. At the same time, the increments and indicators of live weight of animals did not differ from the control indicators. In our opinion, water is not a source of nutrients. Therefore, in the formation of increments, it participates only indirectly and does not depend on the method of drinking. This explains why the weight of the experimental group of foxes, their daily average and absolute increments did not differ from the animals of the first group. However, due to free access to car washes during mechanized drinking, the lack of competition, and therefore the traumas and stress in the foxes of the experimental group in the cages was more calm and comfortable, unlike animals with manual drinking. According to researchers $[16,11]$, the lack of stress factors leads to the production of an endorphin hormone that relaxes the muscles, tones the vessels, normalizes the oxidative processes. Therefore, in the body, the metabolism is normalized, resistance forces (immunity) and adaptability increase. On the contrary, during stress, adrenaline and cortisone are produced. Adrenaline causes activation of the cardiovascular system, evacuation and disintegration of sugar, intensification of the endocrine system, skeletal muscle tone and excitation. Cortisone causes an allergic reaction and the development of antibodies to the pathogenic agent. Under the action of stress hormones, the body is exhausted and illness [23]. Therefore, in our opinion, the animals of the experimental group with mechanized watering did not have a stressful effect on the body. Animals were calm while drinking voluntarily and on demand. Therefore, they did not show aggression to a neighbor on the cell, did not provoke fights and injuries. Therefore, the fur they had without mechanical damage and was $4 \%$ higher than the group of flax defects. In addition, using the nipple autopilots, the water did not wet the fur of the foxes (Vulpes lagopus) of the second group. Therefore, the fur did not wet, chemically did not change, did not contact with dirt. That is why the skins of the experimental group of foxes were estimated at 3\% higher than the size of the gut. Thus, experimentally, the ecological impact and economic and 
technological feasibility of introducing mechanized fishing of fur animals in a fishing farm were proved.

\section{Conclusion.}

The analysis showed that samples of water for manual handing over to the foxes (Vulpes lagopus) and staying in feeders up to 12 hours were characterized by deterioration of organoleptic properties (change in points for odor by 1.1 points, $\mathrm{p}<0.05)$, increase in turbidity (by $1,12 \mathrm{mg} / \mathrm{dm} 3, \mathrm{p}<0.01$ ) and a decrease in $\mathrm{pH}$ (1.06 units, $\mathrm{p}<$ 0.001 ), however, samples of water for mechanized watering on the main parameters of quality remained within the normal range.

Investigation of linear beams of beetles of control and experimental groups did not reveal any significant differences, however, in Group 2 skins were estimated to be $3.9 \%$ higher than control. The conservation of fox population was $3.3 \%$ higher in keeping with animals with mechanized drinking, compared with non-mechanized, there was a decrease in incidence due to illnesses and injuries. Qualitatively, the skins of commodity young foxes (Vulpes lagopus) of the experimental group were characterized by the best color, the highest group of defects and the kind, therefore they were estimated at $48.00 \mathrm{UAH}$ more than animals of the 1st group.

The transfer of the farms to mechanized watering requires investments in the amount of $3147.88 \mathrm{UAH}$. (based on 1 typical shed for 60 cages), while the payback period does not exceed 1.21 years, it is possible to have up to 386.63 net income in revenues for 1 head of the commercial young blue fox (Vulpes lagopus) and achieve a profitability increase of $2.44 \%$.

\section{References}

1. Arctic fox in Norway (2017). Norwegian Environment Agency. https://www.environment.no/topics/biodiversity/species-in-norway/threatened-species/arctic-fox-mainland-norway.

2. Arctic Foxes: The Unintentional Gardeners (2017). http://www.indefenseofplants. com/blog/2017/10/4/arctic-foxes-the-unintentional-gardeners.

3. Bakun, O. M. \& et. (2015). Progressivnyj opyt razvedenija pushnyh zverej $v$ uslovijah lesostepi Ukrainy [Progressive experience of breeding fur animals in the conditions of forest-steppe of Ukraine]. International Scientific Symposium: "Prospects in zootechnics and biotechnology", dedicated to the 75th anniversary of the foundation of the Faculty of Zoology and Biotechnology. Chisinau: Moldova (in Russian).

4. Bala, V. I., Donchenko, T. A., Bezpalyi, I. F., \& Karchenkov, A. A. (2009). Tekhnolohiia vyrobnytstva produktsii krolivnytstva i zvirivnytstva: pidruchnyk [Technology of production of rabbit meat and breeding: a textbook]. Vinnytsia: Nova knyha (in Ukrainian).

5. Balakirev, H. A. \& Judin, V. K. (1994). Postanovka nauchno-hozjajstvennyh opytov po kormleniju pushnyh zverej. Metodicheskie ukazanija [Formulation of scientific and economic experiments on the feeding of fur animals]. Moscow: NIIPZK (in Russian).

6. Bjuleten': Zakonodavstvo Ukraïni: Pro zatverdzhennja Metodichnih rekomendacij z utrimannja hutrovih tvarin [Bulletin: Legislation of Ukraine: On Approval of Methodological Recommendations on the Maintenance of Fur Animals]. Dokument v0379555-08 (2008), potochna redakcija - Prijnjattja vid 20.06.2008 (in Ukrainian).

7. Chikalev, A. \& Juldashev, M. (2012). Zoogigiena: uchenik [Zoohygiene: student]. Moscow: GEOPTAK (in Russian). 
8. Global warming and effects on the Arctic fox. (2008). Science Progress, 91 (2), 175191. doi: $10.3184 / 003685008 \times 327468$.

9. Gugołek, A. \& et. (2010). Digestibilidade dos nutrientes em raposa polar (Vulpes lagopus) alimentada com dietas que continham farinhas de origem animal [Nutrient digestibility in Arctic fox (Vulpes lagopus) fed diets containing animal meals]. Arq. Bras. Med. Vet. Zootec, 62 (4). http://dx. org/10.1590/ S0102-09352010000400026 (in Italian).

10. Hellquist, J. M. (2019). Basic Facts About Arctic Foxes. doi.: https://defenders.org/ arctic-fox/basic-facts.

11. Möstl, E. \& Palme, R. (2002). Hormones as indicators of stress. Domestic Animal Endocrinology, 23 (1-2), 67-74. https://www. ncbi.nlm.nih.gov/pubmed/12142227.

12. Neil, M. L., Barten P. \& Seiser, E. (2000). Foods of Arctic Foxes (Alopex Lagopus) During Winter and Spring in Western Alaska. Journal of Mammalogy, 81 (3), 820-828, https://doi. org/10.1644/1545-1542(2000)081<0820:FOAFAL>2.3.CO;2.

13. Plohinskij N. A. (1969). Rukovodstvo po biometrii dlja zootehnikov [Guide for biometrics for livestock]. Moscow: Kolos (in Russian).

14. Povoznikov, M. G., Shevchuk, T. V. \& Bakun, O. M. (2015). Efektivnist' tehnologichnih prijomiv utrimannja hutrovih zviriv: metodichni rekomendaciï [Efficiency of technological methods of keeping fur-bearing animals: methodical recommendations]. Kyiv, NUBiP (in Ukrainian).

15. Pidpriemstva zvirivnictva ta krolivnictva: VNTP-APK-05.07 (2008) [Enterprises of animal husbandry and rabbit breeding]. Zatverdzheno: nakaz [Minagropolitiki Ukraïni vid 11.03.2008 r. № 131]. Kyiv: Minagropolitiki Ukraïni (in Ukrainian).

16. Rabasa, C. \& L Dickson, S. (2016). Impact of stress on metabolism and energy balance. Current Opinion in Behavioral Sciences, 9, 71-77. https://doi.org/10.1016/j.cobeha.2016.01.011.
17. Rajput, T. B. S. (2010). Role of water management in improving agriculture productivity. Journal article: Indian Journal of Fertilisers, 6 (4), 25-32. https://www.cabdirect.org/?target=\%2fcabdirect\%2fsearch\% 2f\%3fq\%3dau\%253a\%2522Raj.

18. Roth, J. D. (2013).Variability in marine resources affects arctic fox population dynamics. Journal Citation Reports (Ecology), 72 (4), 668-676. https://doi.org/10.1046/ j.1365-2656.2003.00739.x.

19. Scott, D. C. \& Hae, J. K. (2013). Technologies to reduce environmental impact of animal wastes associated with feeding for maximum productivity. Animal Frontiers, 3 (3), 42-47. doi:https//.org/10.2527/af.2013-0023

20. Shherbatij, Z. S. (2003). Problemi stvorennja perspektivnogo norkivnictva $v$ umovah zahidnogo regionu Ukraïni [Problems of prospective promoted rozvedennya minks in the minds of the region of Ukraine] Sil's'kij gospodar.11-12, 27-28 (in Ukrainian).

21. Shkurki pesca golubogo ne vydelannye (1992). Tehnicheskie uslovija: GOST 7907 78 [The blue fox pelts are not trimmed. Technical conditions] - Vzamen GOST 790769; Vved. 01.07.1979. Moscow: Pushno-mehovoe syr'e (in Russian).

22. Sokoljuk, V. M. (2014). Sanitarno-gigienichna ocinka dzherel vodopostachannja dlja napuvannja tvarin u gospodarstvah Ukraïni [Sanitary-hygienic estimation of water supply sources for feeding animals in farms of Ukraine]. Naukovij visnik Bilocerkivs'kogo nac. agrarnogo un.tu. 13 (108), 235-239 (in Ukrainian).

23. Stress, Definitions, Mechanisms, and Effects Outlined (2016). DOI: 10.1016/B9780-12-800951-2.00001-7 In book: Stress: Concepts, Cognition, Emotion, and Behavior, pp.3-11.

24. Umar, S. \& et. (2014). Effects of Water Quality on Productivity and Performance of Livestock: A Mini Review. Veterinary. 2 (2), 11-15. - doi: https://www.researchgate. net/profile/Muahammad_Tanveer_Munir/ publication/284550968. 
25. Visokos, M. P. \& Milostivij, R. V. (2015). Gigiena hutrovih zviriv [Hygiene of fur animals]. Krolikovodstvo i zvirovodstvo. 10 (32), 48-53 (in Ukrainian).

26. Voda pitna. Gigienichni vimogi do jakosti vodi centralizovanogo gospodars'ko-pitnogo vodopostachannja (2010). [Drinking water. Hygienic requirements for the quality of centralized water supply and drink- ing water supply] (DSanPiN 2.2.4-171-10) (in Ukrainian).

27. Voronjak, V. V., Demchuk, M. V. \& Kozenko, O. V. (2006). Metodi ocinki jakosti vodi ta ohorona dzherel vodopostachannja: [metodichnij posibnik] [Methods of water quality assessment and protection of water supply sources: [methodical manual]. L'viv: L'vivs'ka nac. akad. vet. Med. Im.. S.Z. Gzhic'kogo (in Ukrainian).

\section{Т. В. Шевчук, М. Г. Повозніков (2019). ЕКОЛОГІЧНІ ТА ТЕХНОЛОГІЧНІ АСПЕК- ТИ ВИРОЩУВАННЯ ТОВАРНОГО МОЛОДНЯКА ПЕСЦЯ БЛАКИТНОГО (VULPES LAGOPUS) ЗА РІЗНИХ СПОСОБІВ НАПУВАННЯ. ТварИннИЧтво та теХнології харчових продуктів, 10(1): 47-60.}

https://doi.org/

Анотація. Якість води $\epsilon$ однією із головних умов забезпечення нормального функціонування живих істот. За промислового вирощування сільськогосподарських тварин напування відіграє важливу роль. Виробництво екологічно чистої продукції тваринництва на пряму залежить від санітарії та гігієни його технологічних ланок. Тому вивчення екологічних та технологічних аспектів напування сільськогосподарських тварин $є$ актуальним та несе елементи наукової новизни.

У звірівництві тема напування мало вивчена науковцями. Найчастіше звірів напувають вручну. Нами були проведені органолептичні та фрізико-хімічні дослідження проб води за ручного роздавання та механізованого способу напування товарного молодняка блакитного песия (Vulpes lagopиs). Виявлено, що за 2-12 годин після ручного роздавання води у відкриті поїлки достовірно знижується рН води, підвищується каламутність, виникає специфрічний запах та колір. заи механізованого напування песців із індивідуальних напувалок показники води залишаються у межах норми. Експериментально доведено, що спосіб напування не впливає на живу масу та прирости молодняка. Однак, було виявлене підвищення якості шкурок песия (Vulpes lagopus) дослідної групи. За утримання звірів із механізованим напуванням спостерігалось зменшення вад хутра, покращення кольору та гатунку шкурок. Так, у тварин дослідної групи під час оцінки шкурок установлена більша частка виробів першої групи кольору на 2 \%, першої групи вад - на 4 \%, першого гатунку - на 3 \%. Тому шкурки другої групи були оцінені вище за контроль на 48 гривень. Капітальні вкладення за впровадження механізованого напування звірів окупаються за один рік, тому з метою покращення якості хутра, збільшення рентабельності та виробництва екологічно чистої продукції доцільно переводити звірофрерми із ручним напуванням на автоматизоване.

Ключові слова: якість води, звірівничтво, песець блакитний, утримання, напування 